\title{
JAMES DICKSON CARR: FIRST BLACK GRADUATE OF RUTGERS COLLEGE
}

\author{
BY PETER MAZZEI
}

Mr. Mazzei is a member of the staff of Special Collections and Archives, Rutgers University Library

$\mathrm{I}$ $\mathrm{N}$ I 892, within twenty-five years of the New Jersey Legislature's conspicuous reluctance to support ratification of the Thirteenth, Fourteenth and Fifteenth Amendments, only eleven years after New Brunswick less than wholeheartedly discontinued racial segregation in the city's public school system, when blacks comprised only four per cent of New Brunswick's population and were the pariahs of the community, and a "virulent racial prejudice infiltrated every aspect of New Jersey society," James Dickson Carr graduated from Rutgers College, most probably the first black man to complete a baccalaureate degree at Rutgers.

It is noteworthy that before Carr's graduation, very few black men were granted the opportunity to attend, much less graduate from, the elite colleges and universities of the Northeast. Rutgers itself denied admittance to blacks prior to the Civil War period. ${ }^{2}$ By I 890, only four black men had graduated from Harvard, five from Yale, four from the University of Pennsylvania, four from Dartmouth and one from Columbia. Other colleges, such as the City College of New York, Dickinson College and Fordham, did not

' Thus concludes Bruce Ira Goldstein in his study "The Negro in New Jersey I 880- I 920: A History of:Discrimination," Henry Rutgers Scholar Thesis, 1964, p. 82.

${ }^{2}$ Malcolm Connor, "A Comparative Study of Black and White Public Education in Nineteenth Century New Brunswick," New Jersey, Rutgers Doctoral Thesis in Education, 1976, p. 47 :

Negroes who sought admission to Rutgers College were denied acceptance in those decades prior to the Civil War. In the I 850 's the Reverend D. Knox and his wife brought a Negro, Richard Blyden, to New Brunswick from St. Thomas, West Indies for a ". . . collegiate and theological education. Public sentiment was such as to deny him (Blyden) admission to our (Rutgers) College." Dr. Blyden, some years later, gave his account of the incident:

The writer (Blyden) was refused admittance to a literary institution in the United States, on the ground that the faculty had failed to realize their expectations in one or two colored people whom they had educated. This inductive reasoning here employed was ... some colored persons abuse their education, therefore, all colored persons should be excluded from institutions of learning.

(Quoted from Edith Holden, ed., The Story of Blyden, Greenwich, CT: n.p., I 940). 


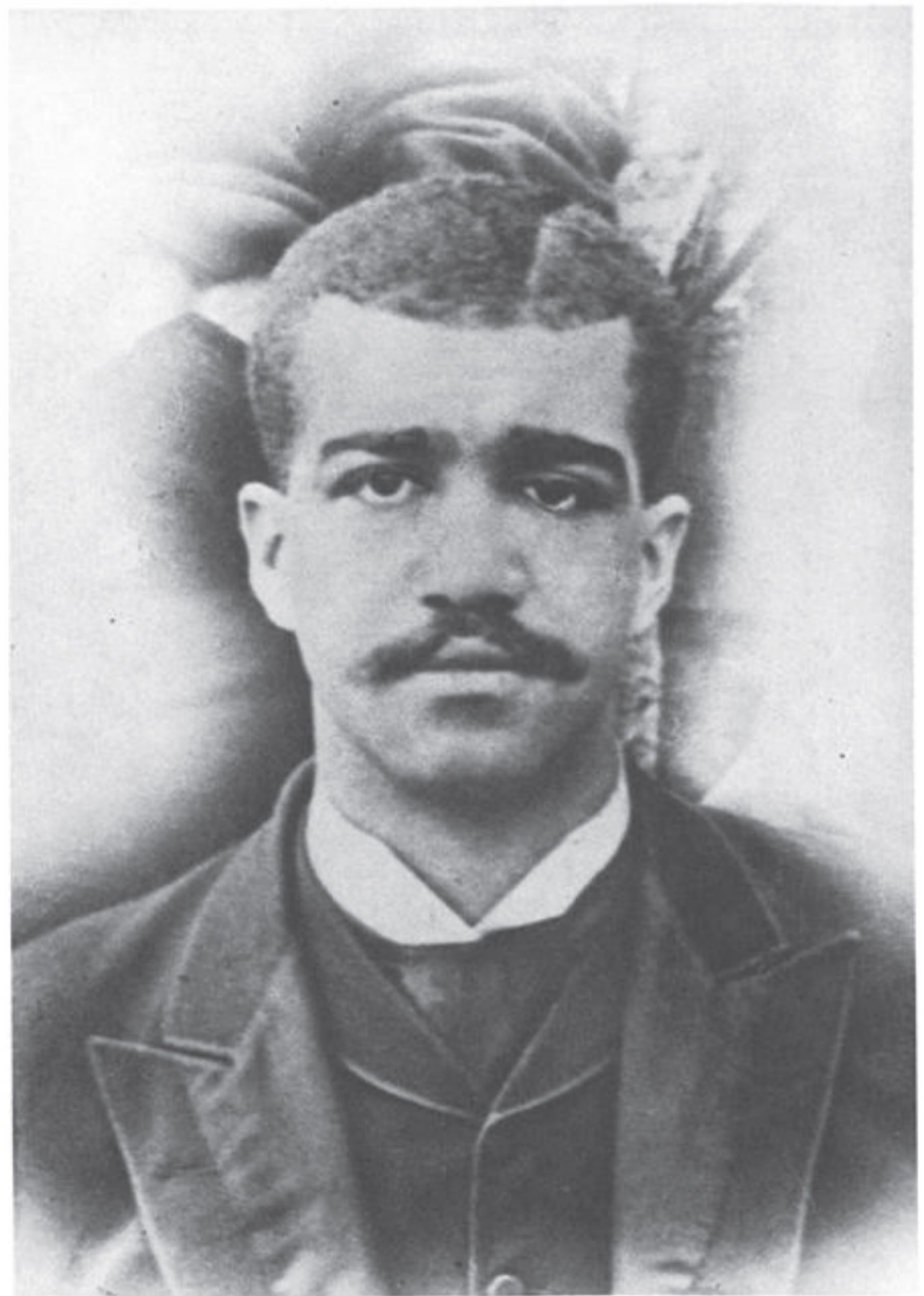

Rutgers University Libraries

Department of Special Collections and Archives

JAMES DICKSON CARR IN 1892. 
graduate black students until after the turn of the century. ${ }^{3}$ Princeton University, moreover, did not admit black students until World War II. ${ }^{4}$

In view of the racism prevalent at this time, one would probably be correct in presuming that Carr experienced some form of prejudice during his college years. However, based on surviving records and documents, evidence suggests that, during Carr's stay at Rutgers, race seems not to have been a significant issue and does not appear to have had any impact on his college career.

Born in Baltimore, Maryland on September 28, I 868, the son of William T. Carr, a Presbyterian minister, and Mary Louise Sprigg Carr, James Carr attended public schools in New Haven, Connecticut and Elizabeth, New Jersey before entering the Rutgers College Grammar School in I 886. Living with his father in Elizabeth, Carr commuted to school until his graduation in I 888 . Although information on Carr's life during those years is scarce, we do know that he graduated at the head of his class. Henry Kimball Davis, a classmate of Carr at the Grammar School and at college, recalled "the School Commencement when Carr spoke the valedictory, thrilling the audience with an oration on John Brown filled with a fire which the boys of today could not hope to approach." 5 The only other extant records of Carr during this period are fragments of his earliest grades at the Grammar School, recorded by Professor William H.S. Demarest, which hint at Carr's outstanding scholastic ability. Carr consistently received almost perfect scores in Latin from the future president of Rutgers College. ${ }^{6}$

The first reference to Carr as a student of Rutgers appears in the Faculty Minutes (June 2 I, I 888) where his name is listed among those of students admitted to the Classical Section of the freshman class. At a time when black enrollment in colleges was something of

3 This is not to say that black men did not graduate from other Northeastern colleges and universities. Indeed, Oberlin College, for example, had a long tradition of admitting and graduating black students. All figures were found in The College-Bred Negro American, edited by W.E.B. DuBois and Augustus Granville Dill, Atlanta University Publications, No. I5, I 9 IO, Pp. 24 and 48.

${ }^{4}$ Laurence R. Veysey, The Emergence of the American University, p. $288 \mathrm{n}$.

${ }^{5}$ Letter from Henry Kimball Davis to Alexander S. Graham, May 31, I932, located in biographical file of James Dickson Carr, Rutgers University Archives.

6 See Demarest's record book of students in Latin and Sciences, Rutgers University Archives, Record Group 4/AII/2. Carr's name is mentioned four times with the following grades: $98,92,99$, and 98 . 
an oddity, it should be mentioned that neither in these minutes, nor in the 'Trustees' Minutes for the same period, is there any record of discussion regarding the admittance of a black student to the college. ${ }^{7}$ With the minor exception of a card kept for the purpose of recording the most recent address of an alumnus, which has "Negro" handwritten under the heading "Remark, "8 not a single college record mentioning Carr refers to his race.

Carr's scholastic record during his four years at Rutgers is quite impressive. Besides earning among the highest grades in the Classical Section of his class, Carr was awarded several honors and prizes throughout college. In his first year, Carr shared the Tunis Quick Prize for Spelling and Grammar, one of only two prizes available to freshmen. As a junior, he was selected as one of eight orators to compete on Commencement Day, June I6, I 89 I. The first prize of that contest was awarded to Philip M. Brett, later to become the acting president of Rutgers College; Carr won honorable mention. ${ }^{9}$ On that same day, Carr was elected and initiated into the Phi Beta Kappa Honor Society, one of eleven students in his class to be a member and one of only five to receive the honor as a junior. ${ }^{\text {Io }}$

A gifted orator, Carr was awarded the Second Bussing Prize in Extempore Speaking in his senior year and was granted the honor, reserved for First Honor students, of delivering the Ivy Oration on campus at the commencement exercises for the Class of I $892 .{ }^{11} \mathrm{~A}$

7 See the Rutgers College Trustee Minutes, I 888-1892; the Executive Committee of the Board of Trustees of Rutgers College, Minutes, I888-1889; the Rutgers College Faculty Minutes, 1888-I 892 where Carr is mentioned several times; and the Rutgers Matriculation Book, Volume I, I 826-I 924, which Carr signed on October 3, I 888.

${ }^{8}$ The remark was most probably written some time after his graduation. The card is located in the biographical file of James Dickson Carr, Rutgers University Archives.

" Carr's speech, entitled "A Nation's Safeguard," was printed in full in the Rutgers Targum, and Series, Vol. XI, No. 18, p. 227.

10 See the Rutgers College Phi Beta Kappa Honor Society Minutes, Vol. I, I869-1 893, p. 246, Rutgers University Archives Record Group 48/EI/I. See also Phi Beta Kappa at Rutgers College I869-1919, printed for the Alpha Chapter of New Jersey, 1920, p. 95.

${ }^{11}$ It is essential to note that, on the same day that Carr gave his oration the Junior Oratory Exhibition was won by A. H. Schlieder for his speech "The Negro-His Rights and Privileges." The text of this speech is reprinted in full:

The I $4^{\text {th }}$ amendment of the Constitution had special reference to the condition of the colored people of the South, and its design was to lift them to the same level as the white people, politically and civilly, and also to enable the general government to protect them in the enjoyment of these rights. In the matter of rights and privileges there is no white and no black man; all are simply men and subject to the same responsibilities. But are we willing to grant them these rights. No, for we fear "Negro Rule." Everywhere it is proven that the negro is a man when he is treated as such. He is as capable as a white man to be at the head, for education and experience qualifies any man to fill even the 
portion of his farewell address to Rutgers, which poignantly expresses his loyalty to the college that granted him the equal opportunity to an education, is reproduced here:

Starting out on our college course, in many things in which our minds were almost as dark as chaos before the infant sun had tried its beam, we have been enlightened. Slowly they have expanded under the sunlight of truth, thought, the guidance of beloved professors. . . .

As we stand upon the world's broad threshold and catch a glimpse of that stage on which every man must play a part, some of us a sad one, with manhood as the one immortal thing, with our motto "excelsior," let us play our part with confidence, ever cherishing in fond memory the lessons we have learned at our Alma Mater, resolving never to shame nor forsake her, but where for her danger or dishonor lurks, to guard her, or with her endure the worst. ${ }^{12}$

In his social life, Carr seems to have been well known on campus and accepted by his peers for the sincerity of his friendship. Davis remembered Carr "as one of the best known of New Brunswick students" and was impressed by:

the respect in which Carr was always held by his fellow students. This was due, I think, to his sincerity and his self-respect. He was never "a butter-in," to apply modern words to old surroundings. He did not want to be patronized; and if any one was inclined to pass him by because of his color, Carr at least would not notice it. Meet him half way, however, and you found a first class fellow, true as steel in his friendship without dissimulation and clean as a hound's tooth in speech and in his private life. ${ }^{13}$

In the Rutgers student newspaper, the Targum, Carr is mentioned in the same jovial spirit ${ }^{14}$ as other students and never is there a ref-

highest office of state. Should the thousands of colored young men who are being educated throughout the South be crowded to the wall on account of prejudice? Would any state permit their white sons to suffer as the negro has been made to suffer? The negro will gain his rights. The South can enact no law bitter enough to hinder him, for he has been progressing in all directions, is becoming more moral in his conduct, more temperate in his religious zeal and more cultural in mind.

(The Rutgers Targum, 2nd Series, Vol. XII, No. 3 I, p. 257.) That a student was awarded first prize for this speech, delivered on the same night of Carr's graduation, further indicates that the prevailing view at Rutgers was one of opposition to racism.

${ }_{12}$ The full text of Carr's oration appeared in the Rutgers Targum, and Series, Vol. XII, No. 3I, p. 253.

${ }_{13}$ Rutgers Alumni Quarterly, October, I920, p. 57.

${ }^{14}$ See, for example, page 35 of the Targum, 2nd series, Vol. XII, No. 5: "Pres. Scott: Will you take my note?"

Mr. C-rr: "Not unless it is endorsed." 
erence to his race. And in the Rutgers student yearbook, the $S$ carlet Letter, Carr is given the same attention as other students of his class. ${ }^{15}$ Nor is Carr excluded from any of the surviving group photographs of the Class of $1892 .{ }^{16}$

Rutgers provided an experience for Carr which at least on the surface ran counter to the pattern of segregation that was commonplace nationwide until well into the twentieth century. When Winants Hall, the Rutgers student dormitory, first opened in I890, Carr, then a junior, shared a room with a white student. ${ }^{17}$ And, although not affiliated with a fraternity, Carr actively participated in several student organizations on campus. A devoted member of the Philoclean Literary Society, ${ }^{18}$ of which he was elected president, Carr was also a member of the Rutgers YMCA, the Rutgers Athletic Association, the Republican Club, the Rutgers Temperance Association and, of course, the Phi Beta Kappa Society. Moreover, Carr's exclusion from the Rutgers athletic teams of his day does not seem to be on account of his color. According to Davis, "an accident in early life had deprived (Carr) of the sight of an eye, and this, together with a somewhat frail physique, barred him from the more active athletics. . .."19

After graduating from Rutgers, Carr entered the Columbia Law School in September I 892 and attended classes at the School of Po-

It must be emphasized that mockery is not the intent of this jest; it was common for students to joke amongst themselves in this way. Rather, the jest reveals that Carr was accepted as one of the crowd.

is See, for example, the Scarlet Letter for the Class of I 892 , p. I 48 , where, in a compilation of personal facts of each graduating member of the class of 1892 , we find the following information about Carr:

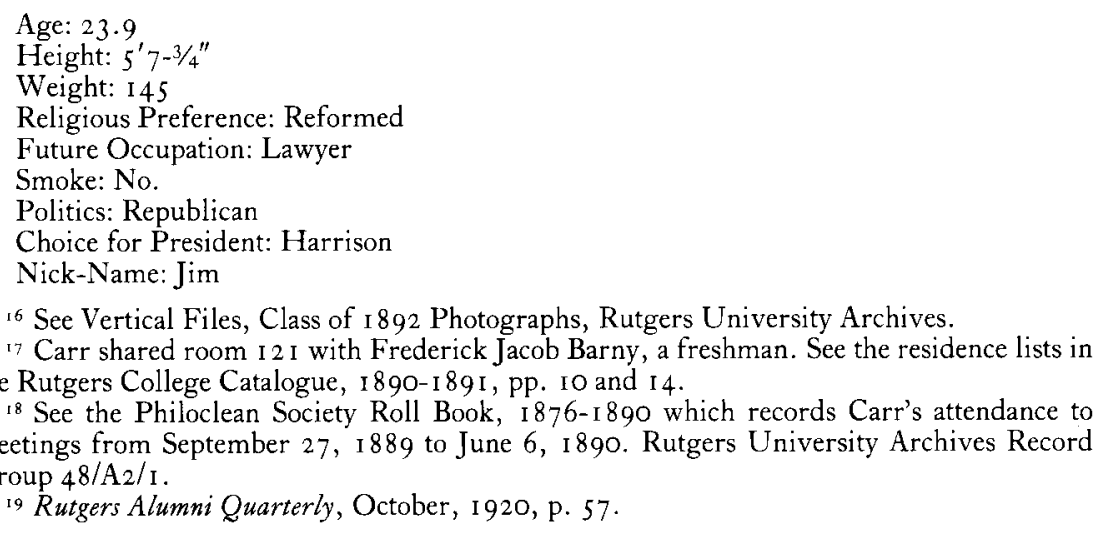


litical Science of Columbia University. Receiving the LL.B. degree in June 1896, he was admitted to the New York Bar in the same month. For the next three years, Carr independently practiced law in New York City, with offices at least part of this time at 23 Chambers Street. Joining Tammany Hall in I 897, Carr became one of the chief factors in establishing the Tammany Hall United Colored Democracy. A dispute with Lemuel E. Quigg, then chairman of the New York County Republican Committee, led to Carr's becoming a Democrat in the late I 890's, despite his being an ardent Republican prior to this time. In September I 899, Carr was appointed Assistant District Attorney of New York County by Asa Bird Gardner and served in this position until April r 90I. At about this time, he became a member of the New York County Lawyer's Association. Three years later, in March I904, Carr was appointed Assistant Corporation Counsel of the New York City Law Department where he was attached to the Bureau of the Recovery of Penalties, eventually to become in charge of the prosecution of abandonment, aged parent and bastardy proceedings. While in this capacity, he married Lillie M. Forrester in New York City on July 7, I 9 I 5 , but did not have children. He remained as the Assistant Corporation Counsel until his death of heart failure in his Harlem home on July 24, I 920. Carr had converted to Catholicism a few years before he died, and his funeral was held at the Church of St. Benedict the Moor in New York City. Just months before, Carr had been scheduled to be appointed a New York City judge by Mayor John J. Hylan. ${ }^{20}$

About a year before his death, Carr wrote a letter to Rutgers' president Demarest expressing his shock and indignation over the Rutgers football team's withdrawal of Paul Robeson from a game upon the request from an all-white team that refused to compete against an opponent with a black player. The text of this remarkable letter ${ }^{21}$ is printed here in full:

President William H.S. Demarest, LL.D.,

June 6, I919

Rutgers College,

New Brunswick, N.J.

\footnotetext{
${ }^{20}$ Information on Carr's life subsequent to his graduation from Rutgers was taken from various sources found in his biographical file, Rutgers University Archives.

${ }^{21}$ The original letter is located in Carr's biographical file, Rutgers University Archives.
} 
Dear Sir:-

During the celebration of the one hundred and fiftieth anniversary of Rutgers College, a statement appeared in the public press that Washington and Lee University, scheduled for a football game with Rutgers, had protested the playing of Paul Robeson, a regular member of the Rutgers team, because of his color. In reading an account of the game, I saw that Robeson's name was not among the players. My suspicions were immediately aroused. After a considerable lapse of time, I learned that Washington and Lee's protest had been honored, and that Robeson, either by covert suggestion, or official athletic authority, had been excluded from the game.

You may imagine my deep chagrin and bitterness at the thought that my Alma Mater, ever proud of her glorious traditions, her unsullied honor, her high ideals, and her spiritual mission, prostituted her sacred principles, when they were brazenly challenged, and laid her convictions upon the altar of comprise.

Is it possible that the honor of Rutgers is virile only when untested and unchallenged? Shall men, whose progenitors tried to destroy this Union, be permitted to make a mockery of our democratic ideals by robbing a youth, whose progenitors helped to save the Union, of that equality of opportunity and privilege that should be the crowning glory of our institutions of learning?

I am deeply moved at the injustice done to a student of Rutgers, in good and regular standing, of good moral character and splendid mental equipment, - one of the best athletes ever developed at Rutgers, - who, because guilty of a skin not colored as their own, was excluded from the honorable field of athletic encounter, as one inferior, and from those lists in which so many competitors for glory were engaged, in which he had formerly been, and into which, with a humiliating tardiness, he was afterwards admitted. He was robbed of the honor and glory of contending in an athletic contest for his college before an assembled multitude composed of representative men and women, of various avocations, from all the corners of the earth. Not only he, individually, but his race as well, was deprived of the opportunity of showing its athletic ability, and, perhaps, its athletic superiority. His achievements on that day may have been handed down as traditions not only to honor his Alma Mater, but, also, to honor himself, individually, and his race, collectively. What an awful spectacle, one of Rutgers' premier athletes on the side lines because of his color! Can you imagine his thoughts and feelings when, in contemplative mood, he reflects in the years to come that his Alma Mater faltered and quailed when the test came, and that she preferred the holding of an athletic contest to the maintenance of her honor and principles?

I am provoked to this protest by a similar action of the University 
of Pennsylvania, heralded in the public press less than two weeks ago. Annapolis protested the playing of the Captain of one of the athletic teams of the University of Pennsylvania, a Colored man. Almost unanimously his fellow athletes decided to withdraw from the field and cancel the contest. In this, however, they were overruled by the athletic manager, who ordered the games to proceed. One of the University's premier athletes on the side lines because of his color! Such prostitution of principle must cease, or the hypocrisy must be exposed.

The Trustees and Faculty of Rutgers College should disavow the action of an athletic manager who dishonored her ancient traditions by denying to one of her students, solely on account of his color, equality of opportunity and privilege. If they consider an athletic contest more than the maintenance of a principle, then they should disavow the ideals, the spiritual mission and the lofty purposes which the sons of Rutgers have ever believed that they cherished as the crowning glory of her existence. May we fervently pray that the Sun of Righteousness may shine upon our beloved Alma Mater, now growing and blossoming into the full fruition of her hopes.

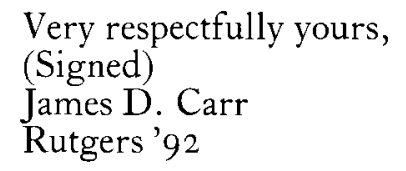

In this letter, written twenty-seven years after his graduation, Carr implicitly contrasted the unbiased treatment that he received at Rutgers with the racial prejudice that excluded Robeson from an athletic event. Certainly, Carr was outraged because an opportunity had been denied to a black man solely because of his color. But his shock and disillusion can be understood only if Carr counted himself among "the sons of Rutgers" who associated their college with the highest democratic ideals. Carr's college experience evidently was such that he could identify his Alma Mater for the maintenance of the principle of granting all students "that equality of opportunity and privilege," regardless of color.

Demarest's reply ${ }^{22}$ to the letter, printed below, could only have been as disappointing to Carr as the Robeson incident was disillusioning:

${ }^{22}$ A copy of Demarest's reply to Carr was found in the Inactive Office Files of President William H.S. Demarest, Rutgers University Archives Record Group 4/A I I/3. 
Mr. James D. Carr,

June I6, I9I9.

258 West 53 rd. Street,

New York City.

My dear Mr. Carr:-

I have your letter with regard to Mr. Robeson and am sorry that there was any incident such as you relate. I have a vague recollection of some discussion at that time but have not clearly in mind the exact details. It is entirely possible to say, however, that Mr. Robeson has received in a very constant and prevailing way the highest regard from every one in all relations as he deserved. He has been an excellent student, making Phi Beta Kappa and was one of the three speakers in the Commencement program. Among the students in athletic relations and otherwise he has been much respected. If there was a single untoward incident in his four year's record, I am sorry.

With best regards,

Very sincerely yours, 